\title{
LIETUVOS KŪNO KULTŪROS AKADEMIJOS GRAIKŲ-ROMĖNŲ IMTYNIŲ RINKTINĖS NARIŲ ATLIEKAMŲ METIMŲ PER NUGARĄ EFEKTYVUMAS
}

\author{
Adolfas Liaugminas ${ }^{1}$, Saulius Liaugminas ${ }^{1}$, Vida Ivaškienè ${ }^{1}$, Kęstutis Raškevičius ${ }^{2}$ \\ Lietuvos kūno kultüros akademijal, Kauno technologijos universitetas ${ }^{2}$, Kaunas, Lietuva
}

\begin{abstract}
Adolfas Liaugminas. Docentas socialinių mokslų daktaras. Lietuvos kūno kultūros akademijos Dvikovos sporto šakų katedros docentas. Mokslinių tyrimų kryptis - imtynininkų rengimo aspektai.
\end{abstract}

\section{SANTRAUKA}

Tyrimo tikslas - nustatyti Lietuvos kūno kultūros akademijos (LKKA) graiku-roménu imtyniu rinktinès nariu atliekamu metimu per nugarq efektyvuma.

Tyrimo metodai: literatūros šaltiniu analizè, pedagoginis stebëjimas, matematinè statistika.

Buvo tiriama 10 didelio meistriškumo LKKA graiku-romėnu imtynininku (2 Lietuvos rinktinès nariai, 2 kandidatai i Respublikos rinktinę, 6 aukštuju mokyklu I II vietu laimètojai). Pedagoginis stebejjimas ir atliekamu veiksmu registravimas vyko 2005-2007 metais šešiose aukšto lygio varžybose (2 Lietuvos aukštuju mokyklu pirmenybèse, 2 tarptautiniuose R. Bagdono vardo turnyruose, 2 Lietuvos čempionatuose).

A. A. Novikovas ir kt. (Новиков и др., 1987) pažymi, kad vienai imčiai užimant stovima padèti vidutiniškai tenka 4-6 juvertinti veiksmai. Kylant imtynininku svorio kategorijai, atliekamu veiksmu kiekis mažeja, tačiau ju atlikimo efektyvumas nekinta. Todèl tiriamuju svorio kategorija nebuvo fiksuojama.

Buvo stebima ir registruojama, kiek tiriamieji per šešerias varžybas iš viso atliko arba bandè atlikti (metimas nebuvo iskaitytas) metimu per nugarq. Veiksmu efektyvumas buvo apskaičiuotas pagal A. Novikovo (Hовиков, 1976) aprobuota formulę. Rodiklis apibüdina imtynininku puolamuju veiksmu efektyvuma ir sportininko meistriškumo lygi. Šis stipriausiu pasaulio imtynininku rodiklis yra lygus 0,55-0,60. Jei jis siekia 0,50-0,54-yra geras, jei 0,40—0,49-patenkinamas.

Tyrimo duomenys parode், kad LKKA graiku-romènu imtyniu rinktinès nariai dažniausiai atlieka metimus per nugara, sugriebdami už kitavardès rankos ir liemens - 166 (51,2\%). Šiek tiek rečiau atliekami metimai per nugara, sugriebus už kitavardès rankos ir sprando - 46,2\%. Gana retai atliekami metimai sugriebus varžovq kitokiais büdais $-2,6 \%$.

Iš viso LKKA graiku-romėnu imtyniu rinktinès nariu atliktu 346 metimu per nugarq buvo ¿̇vertinti 158 (45,7\%). Iš visu tiriamuju realiu bandymu atlikti metimus per nugarq nę̇vertinta buvo 188 (54,3\%).

Palyginus su geriausiais pasaulio imtynininkais, LKKA graiku-romėnu imtyniu rinktinès nariu metimu per nugara efektyvumo lygis yra patenkinamas $(0,46)$.

Rekomendacijos: atkreipti graiku-romènu imtynininku dèmesi i parengiamuosius technikos ir taktikos veiksmus, apgaulingus judesius, norint realizuoti iš anksto numatyta veiksma.

Raktažodžiai: graiku-romènu imtynès, metimai per nugara, efektyvumas.

\section{IVADAS}

I mtyniu specialisto rengimas - tai visuminis pedagogo asmenybès, visapusiškas jo kompetencijos plètojimas ir gebejjimas pagal kvalifikaciją, žinias, igūdžius, varžybinès veiklos patyrimą gerai atlikti savo darbą. Mokykla yra tokia, koks yra mokytojas. „Visur mokyklos verte prilygsta jos mokytojo vertei““ (Distervergas, 1988).
Idomias mintis pateikè J. A. Komenskis (1986) sakydamas, kad ,žmones išmintingus padaryti gali tik išmintingasis, iškalbingus - tik iškalbingasis, dorus - dorasis“. Prie šio autoriaus minčiu galima drąsiai pridèti: „darbščius - darbštusis, gabius - gabusis“ ir t. t. Imtyniu specialistams žinoma, kad metimai per nugarą užima gana sva- 
rią vietą imtynininkų technikos ir taktikos srityje. Šia tema savo požiūrị išreiškia daugelis sporto mokslininkų, imtyniu specialistų - A. P. Kupcovas (Купцов, 1978), N. А. Lencas (Ленц, 1979), Č. T. Ivankovas (Иванков, 1980), E. Kosoj ir kt. (Косой и др., 1981), V. V. Moroz (Мороз, 1983) ir kt. Todèl norédami tobulinti imtynių specialistu rengimą pirmiausia turime išsiaiškinti ne tik atskiru veiksmų atlikimo metodiką, bet ir tų veiksmu efektyvumą varžybinejje veikloje. Tačiau Lietuvoje šie klausimai nagrinejjami menkai.

Manome, kad mūsų respublikos imtynių specializantams ir dirbantiems imtynių treneriams bus aktualu susipažinti su šia metodika bei palyginti geriausių pasaulio atletų meistriškumą pagal varžybinès veiklos, atliekant technikos veiksmus, efektyvuma, aptarti su savo auklètiniais.

Tyrimo tikslas - nustatyti LKKA graikųromėnų imtynių rinktinès narių atliekamų metimų per nugarą efektyvumą.

\section{Uždaviniai:}

1. Nustatyti, kokie metimo per nugarą variantai dažniausiai atliekami varžybose.

2. Išaiškinti, kiek metimų per nugarą iš realių bandymų buvo įvertinti.

3. Nustatyti, kiek realių bandymų atlikti metimus per nugarą nebuvo įvertinti.

4. Nustatyti LKKA studentų graikų-romėnų rinktinès narių metimų per nugarą efektyvumo lygi.

\section{TYRIMO METODIKA IR ORGANIZAVIMAS}

Tyrimo metodai: literatūros šaltinių analizè, pedagoginis stebėjimas, matematinè statistika.

Buvo tiriama 10 didelio meistriškumo LKKA graikų-romėnų imtynininkų (2 Lietuvos rinktinès nariai, 2 kandidatai į Respublikos rinktinę, 6 aukštujų mokyklų I-II vietų laimètojai). Pedagoginis stebejimas ir atliekamų veiksmų registravimas vyko 2005-2007 metais šešiose aukšto lygio varžybose (2 Lietuvos aukštujų mokyklų pirmenybèse, 2 tarptautiniuose R. Bagdono vardo turnyruose, 2 Lietuvos čempionatuose).

A. A. Novikovas ir kt. (Новиков и др., 1987) pažymi, kad vienai imčiai užimant stovimą padeti vidutiniškai tenka $4-6$ ịvertinti veiksmai. Kylant svorio kategorijai, atliekamu veiksmu kiekis mažèja, tačiau jų atlikimo efektyvumas nekinta. Todèl svorio kategorija nebuvo fiksuojama.

Buvo stebima ir registruojama, kiek tiriamieji per šešerias varžybas iš viso atliko arba bandè atlikti (metimas nebuvo iskaitytas) metimų per nugarą.
Veiksmų efektyvumas apskaičiuotas pagal A. Novikovo (Новиков, 1976) aprobuotą formulę:

$$
K_{e f}=\frac{n_{1}}{n_{2}},
$$

čia $\mathrm{K}_{\mathrm{ef}}$ - efektyvumo rodiklis; $\mathrm{n}_{1}$ - ivvertintų veiksmų skaičius; $\mathrm{n}_{2}$ - visų realių atakų skaičius.

Šis rodiklis yra kriterijus, apibūdinantis imtynininkų puolamujų veiksmų efektyvumą ir sportininko meistriškumo lygị. Stipriausių pasaulio imtynininkų šis kriterijus lygus $0,55-0,60$. Jei jis siekia $0,50-0,54$, yra geras, jei $0,40-0,49-$ patenkinamas.

\section{REZULTATAI}

Lietuvos rinktinès narys A. L. iš viso realių bandymų atliko 35 , iš jų $18(51,4 \%)$ buvo ịvertinti, 17 (48,6\%) - neivertinti (žr. lent.). Dažniausiai A. L. atlieka metimą per nugarą sugriebdamas kitavardę ranką ir sprandą. Šis veiksmas iš jo visų atliekamų metimų per nugarą sudaro $48,4 \%$. Buvo ivertinta šių veiksmų 56,2\% A. L. metimus per nugarą atlieka i abi puses. Jo kiekybinis efektyvumo rodiklis $-0,51$. Stipriausiu pasaulio imtynininku šis rodiklis yra lygus $0,55-0,60$. Lyginant A. L. rodikli su standartiniu, skirtumas gana mažas 0,04 . Tai rodo gerą šių veiksmų efektyvumą.

Kitas Respublikos rinktinès narys M. M. (2006 m. Europos čempionato prizininkas) realiu bandymų atliko 36 , iš jų $20(55,4 \%)$ - rezultatyvūs, 16 baigèsi nesékmingai (ivertinant). Per šešerias varžybas $M$. M. metimus per nugara, sugriebdamas kitavardę ranką ir liemeni, atliko 21 kartą, t. y. $60 \%$ visų jo atliekamų metimų per nugarą. Ivertinta buvo $57,1 \%$. M. M. ši veiksma atlieka $\mathfrak{i}$ vieną ir í kitą pusę. Veiksmą atlieka su parengimu - taktiniais, apgaulingais judesiais. Palyginus jo efektyvumo kiekybini rodikli $(0,56)$ su standartiniu $(0,55-0,60)$ matyti, kad M. M. metimų per nugarą efektyvumas yra labai geras.

Respublikos rinktinès narys E. M. iš viso realių bandymų atliko 30, iš jų 15 (48,3\%) ivvertinta ir $16(51,7 \%)$ neivertinta. Iš visų atliekamų metimu 53,3\% tenka metimui per nugarą sugriebiant kitavardę ranką ir sprandą. Ivertinta $56,2 \%$ šiu metimų. Tarp E. M. veiksmų šis metimo būdas nèra pagrindinis. Matyt, jis neskiria didesnio dèmesio šio veiksmo parengimui. E. M. metimo per nugarą efektyvumo rodiklis yra lygus 0,48 . Palyginus su standartiniu rodikliu, jo efektyvumo skirtumas - 0,07. Tai yra patenkinamas efektyvumo rodiklis. 


\begin{tabular}{|c|c|c|c|c|c|c|c|}
\hline $\begin{array}{l}\text { Eil. } \\
\text { Nr. }\end{array}$ & Inicialai & $\begin{array}{c}\text { Neivertintų me- } \\
\text { timų skaičius }\end{array}$ & $\begin{array}{l}\text { Ivertintų meti- } \\
\text { mų skaičius }\end{array}$ & $\begin{array}{l}\text { Iš viso realių } \\
\text { bandymų } \\
\text { skaičius }\end{array}$ & $\begin{array}{c}\text { Efektyvumo } \\
\text { rodiklis }\end{array}$ & $\begin{array}{c}\text { Stipriausių pasaulio } \\
\text { imtynininkų efekty- } \\
\text { vumo rodiklis }\end{array}$ & \multirow{12}{*}{$\begin{array}{l}\text { Lentelè. LKKA } \\
\text { graikų-romèn ų } \\
\text { imtynių rinktinès } \\
\text { narių atliekamų } \\
\text { metimų per nugarą } \\
\text { duomenys }\end{array}$} \\
\hline 1. & A. L. & 17 & 18 & 35 & 0,51 & \multirow{10}{*}{$0,55-0,60$} & \\
\hline 2. & M. M. & 16 & 20 & 36 & 0,56 & & \\
\hline 3. & E. M. & 16 & 15 & 31 & 0,48 & & \\
\hline 4. & V. . S. & 17 & 15 & 32 & 0,47 & & \\
\hline 5. & B. D. & 17 & 14 & 31 & 0,45 & & \\
\hline 6. & E. J. & 19 & 17 & 36 & 0,47 & & \\
\hline 7. & R. J. & 11 & 9 & 20 & 0,45 & & \\
\hline 8. & R. I. & 24 & 20 & 44 & 0,45 & & \\
\hline 9. & K. Š. & 27 & 16 & 43 & 0,37 & & \\
\hline \multirow[t]{2}{*}{10.} & A. Ž. & 24 & 14 & 38 & 0,37 & & \\
\hline & Iš viso & 188 & 158 & 346 & 0,46 & & \\
\hline
\end{tabular}

Respublikos rinktinès kandidatas V. $\breve{S}$. iš viso realių bandymų atliko 31 , iš kurių $15(46,8 \%)$ įvertinti ir $17(53,2 \%)$ neivertinti. $61,2 \%$ tenka metimui per nugara, sugriebiant kitavardę ranką ir liemeni, o $38,8 \%$ tenka metimams per nugarą iš kitų padéčių. Ivertinta metimu sugriebiant kitavardę ranką ir liemeni buvo $57,8 \%$. Metimu per nugarą efektyvumas siekia 0,47 . Tai patenkinamas rodiklis.

Respublikos rinktinès kandidatas B. D. iš viso realiu bandymų atliko 31, iš jų buvo izvertinti 14 $(45,3 \%)$ ir $17(54,7 \%)$ neịvertinti. Jis dažniausiai atlieka metima per nugara, sugriebdamas kitavardę ranką ir liemeni $-53,1 \%$, iš kuriu ivertinta $47 \%$. 46,9\% tenka kitiems veiksmams. Ši veiksmą atlieka be parengiamujų veiksmų ar judesių. Jo efektyvumo rodiklis yra žemas ir siekia 0,45.

Respublikos aukštuju mokyklų rinktinès narys E. J. iš viso realių bandymų atliko 36 , iš jų 17 $(47,2 \%)$ buvo ịvertinti, $19(52,8 \%)$ - nesèkmingi. Iš visų metimu per nugarą, 58,3\% tenka metimui sugriebiant kitavardę ranką ir sprandą. $62 \%$ šiu veiksmu buvo ivertinti. Kartais E. J. nutraukia sugriebima paleisdamas ranką, dèl to veiksmas nebeatliekamas iki galo. Palyginus jo efektyvumo rodikli su standartiniu, skirtumas lygus 0,08 . Tai patenkinamo efektyvumo rodiklis.

Respublikos aukštujų mokyklų rinktinès narys R. J. iš viso realių bandymų atliko 20, iš jų 9 (45\%) buvo i̇vertinti ir 11 (55\%) neivertinti. Dažniausiai jis atlieka metimus per nugarą sugriebdamas kitavardę ranką ir liemeni. Jų atliko $76,1 \%$ iš visų metimu per nugara, ivertinta buvo $50 \%$. R. J. metimus per nugarą atlieka iš vienos padeties ir tik retai bando atlikti iš kitu, ir tai sumažina rea- lizuoti daugiau ịvertinamų veiksmų. Efektyvumo rodiklis - 0,45 - neblogas (patenkinamas).

Respublikos aukštujų mokyklų rinktinès narys R. I. iš viso realių bandymų atliko 44 , iš kurių buvo ivvertinti $20(45,4 \%)$, neivertinti $24(54,6 \%)$. R. I. dažniausiai atlieka metimą per nugarą sugriebdamas už kitavardès rankos ir sprando. Šis veiksmas sudaro $68,8 \%$ visų metimų per nugara ir buvo ivertinta $45,1 \%$ šiu veiksmų. Metimu per nugara efektyvumo rodiklis - 0,45 (patenkinamas). (Galima pasiekti geresnių rezultatų, jei būtu taikoma įvairesnè metimu per nugarą parengimo ir atlikimo taktika.)

Respublikos aukštujų mokyklų rinktinès narys $\mathrm{K}$. $\breve{S}$. atliko 43 realius bandymus, iš kuriu 16 $(37,2 \%)$ buvo ivertinti ir $27(62,8 \%)$ neivertinti. Šis imtynininkas dažniausiai atlieka metimą per nugarą sugriebdamas kitavardę ranką ir sprandą. Iš $51,2 \%$ veiksmu ivvertinti $33,3 \%$. K. Š. metimu per nugarą efektyvumo rodiklis - 0,37 . Tai žemas efektyvumo lygis, nes šis imtynininkas prieš atlikdamas veiksmą nederina jo su parengiamaisiais veiksmais ar judesiais.

Respublikos aukštuju mokyklų rinktinès narys A. Ž. atliko 38 realius bandymus, iš kuriu $14(36,8 \%)$ buvo ivertinti ir $24(63,2 \%)$ neivertinti. Dažniausiai A. Ž. atlieka metimą per nugarą sugriebdamas už kitavardès rankos ir sprando $-51,3 \%$, iš kuriu ívertinta $34,2 \%$. Šio veiksmo efektyvumo rodiklis labai žemas - 0,37. (A. Ž. šių metimų nejungia į derinius, tik laukia patogios progos — tai ir lemia šio kriterijaus lygi.)

Per stebėtas varžybas graikų-romėnų imtynininkai dažniausiai atliko metimą per nugara 
sugriebdami ranką ir liemeni - $166(51,2 \%)$, metimus sugriebiant kitavardę ranką ir spranda $150(46,2 \%)$, o $2,6 \%$ tenka metimams per nugara sugriebiant varžovą kitais būdais. Iš viso imtynininkai atliko 346 metimus per nugarą, iš kuriu ivertinti 158 (45,7\%) ir neivertinti 188 (54,3\%). Visų tirtų imtynininkų efektyvumo vidurkis patenkinamas (lygus 0,46). Jis skiriasi nuo stipriausiu pasaulio imtynininkų standartinio $-0,09$.

\section{REZULTATU APTARIMAS}

LKKA graikų-romėnų imtynių rinktinès narių atliekamų metimu per nugarą efektyvumas yra nevienodas: efektyvumo rodiklis svyruoja nuo 0,36 iki 0,55 , o stipriausių pasaulio imtynininku siekia $0,55-0,60$. Tarp mūsų tiriamujų buvo tik vienas imtynininkas (M. M.), kurio metimu per nugara efektyvumas atitinka ši stipriausių pasaulio imtynininkų rodikli. Nedaug nuo jo atsilieka imtynininkas A. L., kurio minètu metimu efektyvumo rodiklis yra lygus 0,51 (geras). Minèti imtynininkai metimus per nugarą atlieka į abi puses. M. M. išsiskiria tuo, kad atlieka daug parengiamujų apgaulingu judesių. Tai patvirtina A. A. Karelino (Карелин, 2006), O. B. Malkovo ir kt. (Малков и др., 2007) duomenis, kad didelio meistriškumo imtynininkai naudoja daug parengiamujų apgaulingų veiksmu.

Šešiu imtynininkų efektyvumo rodiklis siekia $0,43-0,48$ ribas, jis yra patenkinamas, tačiau dviejų sportininku - žemas. Visų rinktinès narių vidutinis efektyvumo rodiklis siekia 0,45 (patenkinamas), nuo stipriausių pasaulio imtynininku atsilieka 0,10 .

Išsiaiškinta, kad LKKA graikų-romėnų imtynių specializantai dažniausiai atlieka metimus per nugarą, sugriebdami už kitavardès rankos, liemens arba sugriebdami už kitavardès rankos ir sprando. Pastebèta, kad imtynininkai mažokai naudoja parengiamujų ir apgaulingų judesiu, veiksmų derinius, galbūt dèl to metimų per nugarą efektyvumo rodiklis nèra labai aukštas. Tai sutampa su O. B. Malkovo ir kt. (Малков и др., 2007) nuomone, kurie teigia, kad graikų-romėnu imtynininkai skiria nepakankamai dèmesio parengiamiesiems veiksmams.

Tyrimas parodè, kad norint gerinti LKKA graikų-romėnų imtynininkų sportini meistriškumą reikia daugiau individualizuoti ju technini ir taktini rengimą. Tai patvirtina E. Kosoj ir kt. (Косой и др., 1981), V. V. Morozo (Мороз, 1983), A. A. Novikovo ir kt. (Новиков и др., 1987), A. A. Karelino (Карелин, 2006), O. B. Malkovo ir kt. (Малков и др., 2007) nuomonę - kylant sportiniam meistriškumui, imtynininkų parengiamuju, apgaulingų veiksmų, veiksmų derinių daugeja.

\section{IŠVADOS}

1. LKKA graikų-romėnų imtynių rinktinès nariai dažniausiai atlieka metimus per nugarą, sugriebdami už kitavardès rankos ir liemens $166(51,2 \%)$. Šiek tiek rečiau atliekami metimai per nugarą sugriebiant už kitavardès rankos ir sprando - 46,2\%. Gana retai atliekami metimai sugriebiant varžovą kitokiais būdais $2,6 \%$.

2. Iš LKKA graikų-romėnų imtynių rinktinès narių atliktų 346 metimų per nugarą buvo įvertinti $158(45,7 \%)$.

3. Iš visų tiriamujų realių bandymų atlikti metimus per nugarą neivertinti buvo 188 (54,3\%).

4. Palyginus su geriausiais pasaulio imtynininkais, LKKA graikų-romènu imtynių rinktinès narių metimų per nugarą efektyvumo lygis yra patenkinamas $(0,46)$.

Rekomendacijos: atkreipti graikų-romėnų imtynininkų demesi i parengiamuosius technikos ir taktikos veiksmus, apgaulingus judesius, norint realizuoti iš anksto numatytą veiksmą.

\section{LITERATŪRA}

Distervegas, A. (1988). Pedagoginiai raštai. Kaunas: Šviesa. P. 74.

Komenskis, J. A. (1986). Pedagoginiai raštai. Kaunas: Šviesa. P. 287

Liaugminas, A., Muckus, K., Skurvydas, A. ir kt. (2007). Graiku-romenu imtynès. Kaunas: LKKA.

Иванков, Ч. Т. (1980). Бросок через спину. Ежегодник «Спортивная борьба». Москва: ФиС.

Карелин, А. А. (2006). Структурно-функциональная модель интегральной подготовленности борца высокой квалификации. Теория и практика физической культуры, 10, 36-38.

Косой, Е., Евдокимов, В., Львов, В. (1981). Совершенствование тренировочного процеса у борцов. Ежегодник «Спортивная борьба». Москва: ФиС.

Купцов, А. П. (1978). Спортивная борьба. Москва: ФиС.

Ленц, Н. А. (1979). Ведущие элементы в сложных технико-тактических действиях. Ежегодник «Спортивная борьба». Москва. С. 19-20.

Малков, О. Б., Чудаков, А. В., Хаустов, А. В. (2007). Маневрирование при выполнении бросков прогибом в 
греко-римской борьбе. Теория и практика физической культуры, 3, 43- 46.

Мороз, В. В. (1983). Прогнозирование эффективности выполнения технических достижений: тез. докл. II всесоюзн. конферениии «Прогнозирование спортивных достижений в системе подготовки высококвалифицированных спортсменов». Москва. С. 75 .
Новиков, А. А., Дахновский, В. С., Разманов, Ф. Ш. (1987). Проблема индивидуализации технической подготовки борцов. Теория и практика физической культуры, 2, 36-37.

Новиков, А. А. (1976). Пути совершенствования в спортивной борьбе. Москва: ФиС.

\title{
THE EFFICIENCY OF THE THROWS OVER THE BACK, PERFORMED BY THE GRECO-ROMAN WRESTLING TEAM MEMBERS OF THE LITHUANIAN ACADEMY OF PHYSICAL EDUCATION
}

\author{
Adolfas Liaugminas ${ }^{1}$, Saulius Liaugminass ${ }^{1}$, Vida Ivaškiené ${ }^{1}$, Kęstutis Raškevičius ${ }^{2}$ \\ Lithuanian Academy of Physical Education ${ }^{I}$, Kaunas University of Technology ${ }^{2}$,
} Kaunas, Lithuania

\begin{abstract}
The objective of the research was to estimate one of the most common actions of LAPE greco-roman wrestlers, performed in the stance during the competitions - the efficiency of the throws over the back.

10 elite greco-roman wrestlers took part in the research (2 members of the Lithuanian National Team, 2 candidates to the National Team and $61^{\text {st }-2^{\text {nd }}}$ place winners in the high schools). Educational observation and the registration of the performed actions were done in 2005-2007 during 6 competitions ( 2 championships of the Lithuanian high schools, 2 international R. Bagdonas Tournaments, 2 Lithuanian Championships).

During these competitions wrestlers performed or tried to perform 346 throws over the back. The efficiency of the actions was evaluated by the formula of A. Novikovas approbated in 1976.

This index is the criteria, which defines the efficiency of the wrestlers' offensive actions and the level of mastership of the sportsmen. The index of the strongest wrestlers of the world is $0.55-0.60$. If it is good, it reaches $0.5-0.54$, and satisfactory $-0.4-0.49$.

The information gathered shows that the greco-roman wrestlers generally perform throws over the back by grasping adverse hand and the waist - $166(51.2 \%)$. Quite rarely the throws are performed by grasping the rival in a different way $-2.4 \%$.

All the evaluated throws over the back numbered 158 (45.6\%), and all the real attempts, that were not evaluated - $188(54.4 \%)$.

In comparison with the best wrestlers of the world the efficiency index of the throws over the back of the LAPE greco-roman wrestlers was satisfactory $(0.45 \%)$.

We would recommend to pay attention to the preparatory technical-tactical actions, dodge, seeking to implement actions planned beforehand.
\end{abstract}

Keywords: greco-roman wrestlers, throws over the back, efficiency.

Gauta 2008 m. gegužès $1 \mathrm{~d}$.

Received on May 1, 2008 